\title{
Diseminasi Informasi Peringatan Dini Tanah Longsor Berbasis Teknologi Internet of Things
}

\author{
1Hapsoro A. Nugroho*), ${ }^{2}$ Ridho Helmi Pratama, ${ }^{1}$ Suharni, ${ }^{1}$ Agus Tri Sutanto, ${ }^{1}$ Hariyanto \\ ${ }^{1}$ Kelompok Kajian Instrumentasi-MKG, Sekolah Tinggi Meteorologi, Klimatologi, dan Geofisika \\ 2Badan Meteorologi, Klimatologi, dan Geofisika
}

hapsoro.agung@bmkg.go.id*)

\begin{abstract}
Abstrak
Tanah longsor merupakan bencana yang terjadi setiap memasuki musim penghujan dan sangat lokal daerah kejadiannya. Akibat bencana ini sangat besar tidak hanya merusak infrastruktur tetapi tidak jarang menimbulkan korban jiwa. Tujuan penelitian ini mengembangkan sebuah sistem untuk memantau bencana tanah longsor berdasarkan parameter curah hujan, kelembapan tanah, serta pergerakan tanah. Ketiga parameter ini telah dilakukan analisis karakteristik berdasarkan daerah penelitian yaitu di Desa Sijeruk, Kecamatan Banjarmangu, Kabupaten Banjarnegara, Jawa Tengah untuk mendapatkan nilai ambang batasnya. Selain itu, sistem juga dapat memberikan peringatan dini secara real time dan lokal berdasarkan tingkat kerawanan rendah, sedang, tinggi dan ekstrim. Teknologi Internet of Things (IOT) diimplementasikan dalam penyimpanan data dan komunikasi pengiriman data. Arduino berperan sebagai publisher dan layanan Thingspeak sebagai broker serta penyimpan data. Sedangkan smartphone pengguna sebagai subscriber yang menampilkan grafik data dan tingkat kerawanan bencana tanah longsor. Hasil menunjukan data parameter curah hujan, kelembapan tanah serta pergerakan tanah dapat terkirim dengan baik. Sistem peringatan dini juga dapat mendiseminasikan informasi tingkat kerawanan longsor ke masyarakat desa setempat.

Kata Kunci: tanah longsor; internet of things; curah hujan; peringatan dini
\end{abstract}

\section{Pendahuluan}

Tanah longsor merupakan salah satu bencana hidrometeorologi yang terjadi dalam waktu yang singkat dan dapat terjadi kembali dalam periode waktu tertentu. Pemicu terjadi tanah longsor dapat disebabkan karena hujan, pergerakan tanah, maupun bentuk lereng suatu tempat [1]. Musim penghujan atau daerah yang mempunyai curah hujan yang cukup tinggi berasosiasi dengan bencana tanah longsor di suatu area [2]. Lokasi penelitian terletak di wilayah Kecamatan Banjarmangu, Kabupaten Banjarnegara, Provinsi Jawa Tengah seperti yang ditampilkan pada gambar 1. Selama kurun waktu Tahun 2011 sampai 2017 tercatat kejadian tanah longsor sebanyak 38 kejadian (Sumber : Badan Penanggulangan Bencana Daerah Kabupaten Banjarnegara), dimana 30 diantaranya disebabkan curah hujan yang tinggi. Catatan kejadian tersebut menimbulkan kerusakan infrastruktur dan korban jiwa yang cukup tinggi. Bila dilihat dari rata-rata kejadian selama kurun waktu tersebut, menunjukan keaktifan bencana tanah longsor di Kecamatan Banjarmangu. Sehingga diperlukan suatu sistem yang dapat memantau dan memberikan informasi secara dini kepada masyarakat setempat sebelum kejadian tanah longsor. Konsep peringatan dini menurut [3] bagaimana informasi tersedia secara tepat melalui sebuah lembaga sehingga dapat bermanfaat bagi seorang individu dalam upaya melakukan tindakan pencegahan. Peringatan dini perlu didukung dengan diseminasi informasi kepada masyarakat yang mempunyai resiko di lingkungannya [4]. Penentuan media komunikasi dalam diseminasi informasi menjadi sangatlah penting, hal ini berkaitan dengan penyampaian informasi dapat diterima secara cepat, tepat dan mudah dipahami. Beberapa penelitian terkait diseminasi informasi tanah longsor dengan menggunakan modem GSM (Global System for Mobile Communications) yang mengirimkan SMS (Short Message Service) [5]. Komunikasi dengan media fiber optic dengan kemampuan full duplex dan dapat mentransmisikan informasi sejauh 2,5 km memberikan hasil yang cukup baik [6].
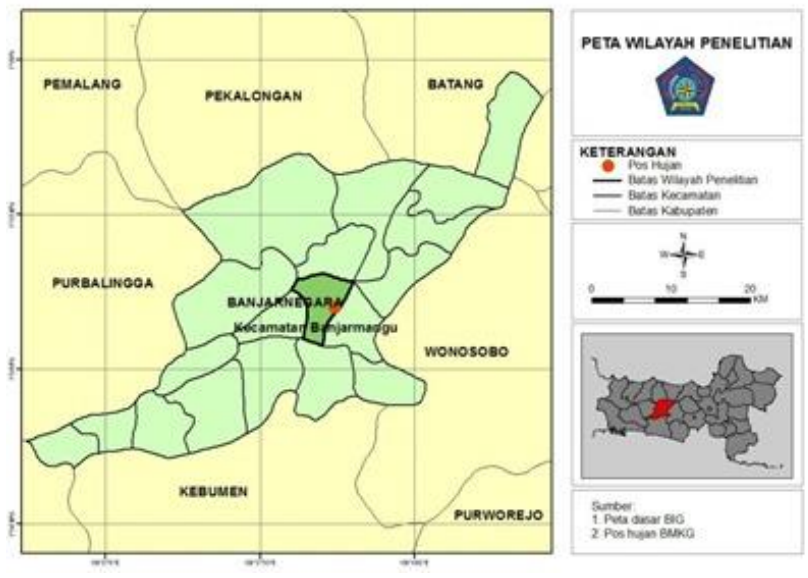

Gambar 1 peta lokasi peneltian

Berkembangnya teknologi informasi dan komunikasi yang ditandai dengan revolusi industri 4.0 mendorong proses diseminasi ini dituntut 
menjadi lebih cepat dan semakin mudah diakses kapan dan dimanapun. Salah satu teknologi tersebut adalah IoT, dimana segala sesuatunya mulai proses dari hulu sampai hilir memungkinkan terhubung dalam suatu jaringan internet. loT dapat diaplikasikan dalam pengembangan smart campus [7], pemantauan pembangkit listrik tenaga surya [8], serta dalam pemantauan bencana alam [9].

Penelitian ini bertujuan memanfaatkan teknologi IoT sebagai diseminasi informasi tanah longsor yang dapat diakses melalui website ataupun smartphone. Informasi tersebut berdasarkan parameter pemicu tanah longsor seperti curah hujan, kelembapan tanah, dan pergerakan tanah. Diseminasi menampilkan pengukuran ketiga parameter tersebut beserta informasi dini tingkat kerawanan longsor, sehingga secara cepat ada keputusan untuk melakukan evakuasi sebelum tanah longsor terjadi.

\section{Desain Sistem dan Implementasi}

Berdasarkan kajian yang telah dilakukan di penelitian sebelumnya [10], sistem yang akan dirancang terdiri atas tiga bagian utama, yaitu Input, Proses, dan Output seperti yang ditunjukan pada gambar 2. Pada bagian Input, terdiri dari tiga sensor yang merupakan bagian pengukuran fisis dari pemicu terjadinya bencana tanah longsor. Pengukuran fisis disesuaikan berdasarkan parameter meteorologi, klimatologi, dan geofisika. Sensor yang digunakan yaitu :

1. Sensor Tipping Bucket digunakan sebagai pengukur curah hujan. Penakar hujan jenis ini paling umum digunakan, prinsipnya terdapat beberapa bagian utama. Pertama adalah bucket atau penampung air hujan berbentuk seperti kerucut. Bagian kedua terdapat sensor magnet (reed switch). Penakar hujan tipping bucket seperti ditunjukan pada gambar 2 .

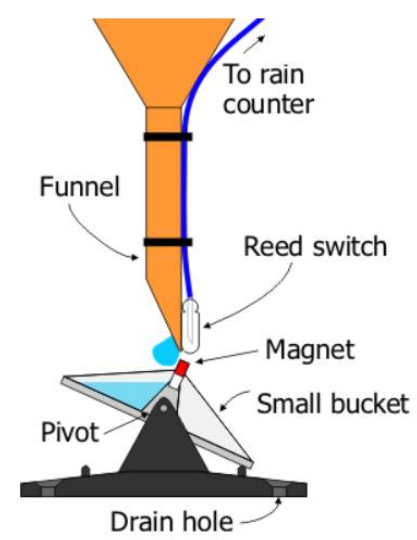

Gambar 2 penakar hujan tipping bucket
2. Sensor Soil Moisture digunakan sebagai pengukur kelembapan tanah. Sensor yang digunakan menggunakan profile probe PR2/6 seperti yang ditunjukan pada gambar 3 .

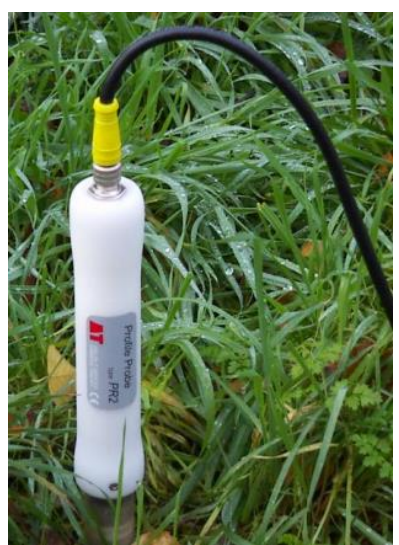

Gambar 3 sensor soil moisture profil probe

3. Sensor Akselerometer digunakan untuk mengukur pergerakan dan perpindahan posisi tanah. Pada gambar 4 menunjukan sensor yang digunakan yaitu microelectronic mechanical system ADXL-345.

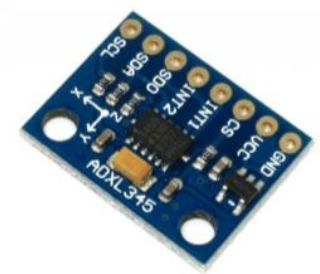

Gambar 4 sensor akselerometer adx|345

Mikrokontroler ATMega2560 sebagai pengolah data utama berada pada bagian proses. Bagian ini memiliki fungsi sebagai pemroses data yang masuk dari sensor, serta sebagai pengatur proses transmisi data yang berlangsung pada sistem. Mikrokontroler berperan juga menghubungkan bagian proses ke output, seperti ke penyimpanan data, display ataupun komunikasi. Sistem pewaktuan dengan RTC (Real Time Clock) untuk menyimpan jam terkini agar sinkron dengan data yang tersimpan. Komunikasi untuk mendukung loT digunakan modul wifi ESP8266, yaitu perangkat tambahan sebagai perantara dari mikrokontroler ke jaringan internet. Jaringan internet ini terkoneksi ke aplikasi thingspeak untuk menampilkan parameter pengukuran sensor dan diseminasi informasi tingkat kerawanan longsor. Thingspeak merupakan sebuah platform open source yang menyedikan fitur berbasis cloud yang memungkinkan untuk menarik data dari sensor untuk disimpan dan kemudian ditampilkan dalam bentuk grafik secara real time menggunakan protokol HTTP, sehingga dapat ditampilkan dalam 
bentuk website maupun smartphone. Desain sistem secara keseluruhan ditunjukan seperti pada gambar 5 .

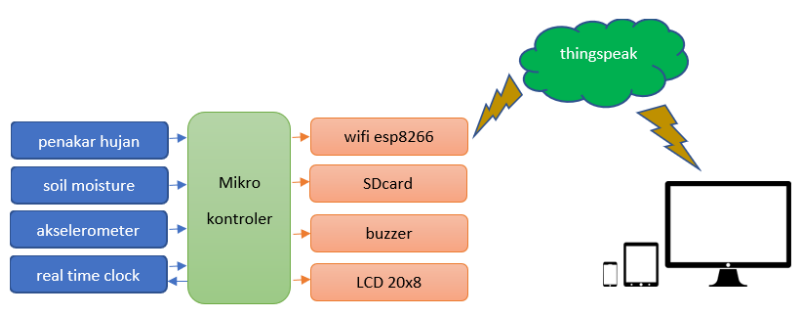

Gambar 5 blok diagram sistem

Implementasi sistem dilakukan pengujian di lokasi penelitian untuk melihat kehandalan komunikasi jaringan internet. Penempatan sistem juga memerlukan desain mekanik yang baik dikarenakan lokasi penelitian sebagian besar lereng yang memiliki kemiringan. Gambar 6 menunjukan proses instalasi sistem secara keseluruhan di lokasi penelitian.

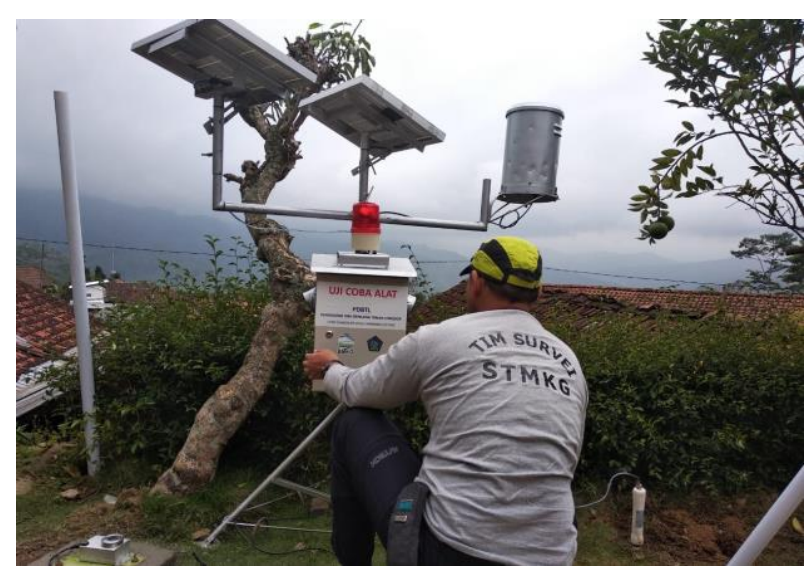

Gambar 6 prose instalasi sistem di lokasi penelitian

Sedangkan pada gambar 7 merupakan sistem secara keseluruhan yang telah beroperasi melakukan monitoring parameter curah hujan, kelmbapan tanah, dan pergerakan tanah. Petugas BPBD Kabupaten Banjarnegara ikut serta membantu dalam instalasi ini. Informasi peringatan dini dapat diakses oleh instansi BPBD maupun masyarakat setempat yang memiliki kerawanan tinggi terhadap bahaya tanah longsor. Instansi BPBD menjadi rantai peringatan dini kepada masyarakat apabila masyarakat mengalami kesulitan untuk mengakses informasi yang dikeluarkan sistem.

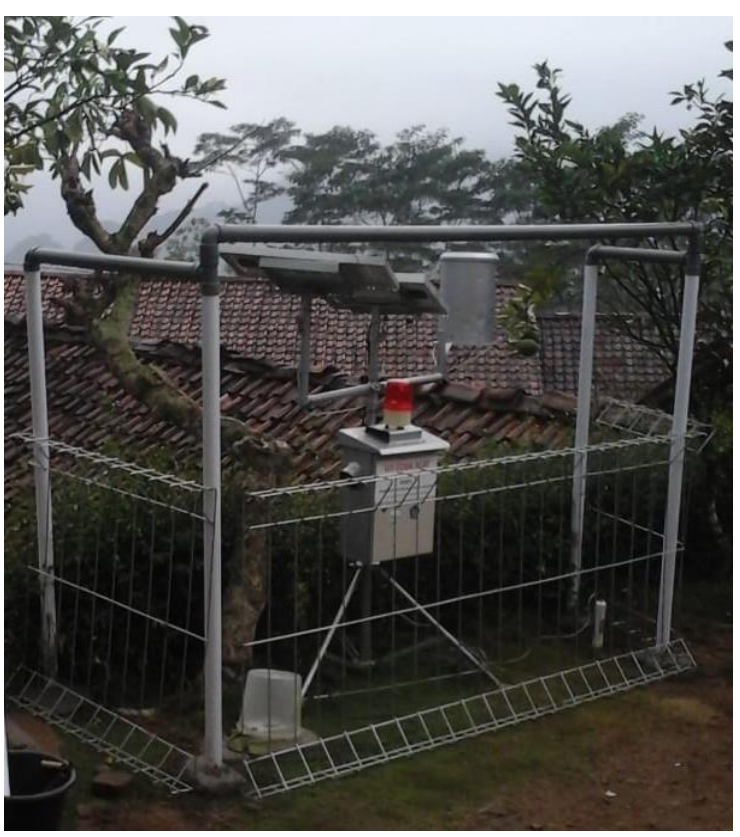

Gambar 7 sistem yang telah beroperasi.

Selanjutnya adalah menganalisis komunikasi untuk melihat konsistensi pengiriman data. Gambar 8 menunjukan selisih waktu pengiriman dalam periode satu hari. Data yang diambil Tanggal 1 November 2018. Terlihat bahwa dalam satu hari rata-rata selisih pengiriman data sekitar 16 detik dengan selisih waktu maksimum sekitar (1 menit 27 detik) atau 97 detik dan waktu minimum sekitar 15 detik. Pengiriman komunikasi terdapat selisih waktu yang belum konsisten, dimana selisih tertinggi sekitar 1 menit. Hal ini kemungkinan disebabkan ketidakstabilan jaringan internet di lokasi penelitian.

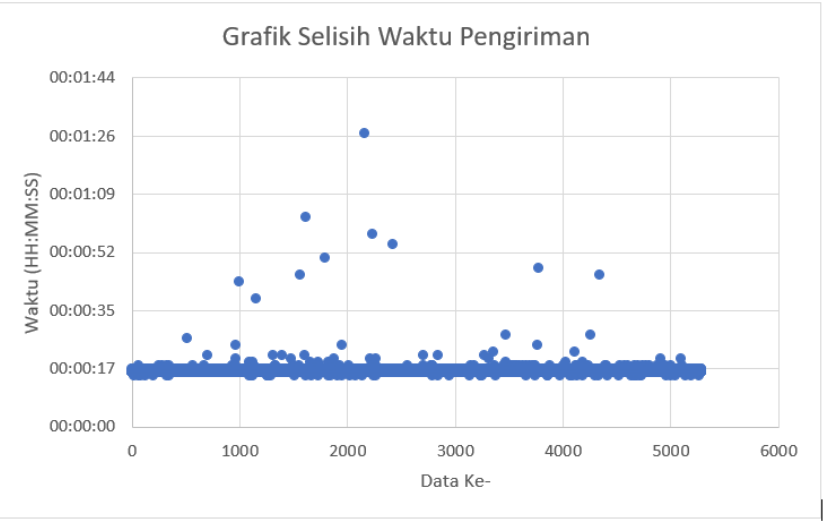

Gambar 8 grafik selisih waktu pengiriman data

Masyarakat atau BPBD setempat dapat mengakses aplikasi thingspeak melalui website ataupun aplikasi thingview pada smartphone. Gambar 9 merupakan tampilan aplikasi thinkspeak yang dapat diakses melalui alamat thingspeak.cpm/channels/539055. 


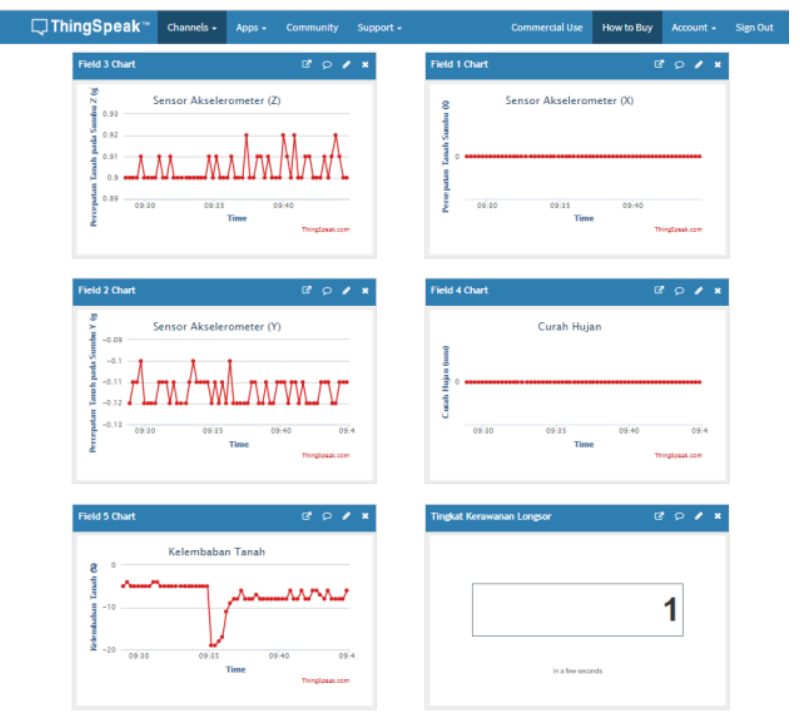

Gambar 9 tampilan pada website

Pada gambar 10 merupakan tampilan pada aplikasi mobile yang berisi informasi parameter curah hujan, kelembapan tanah, pergerakan tanah serta informasi peringatan dini. Peringatan $1=$ rendah, 2 = sedang, 3 = tinggi, dan 4 = ekstrim

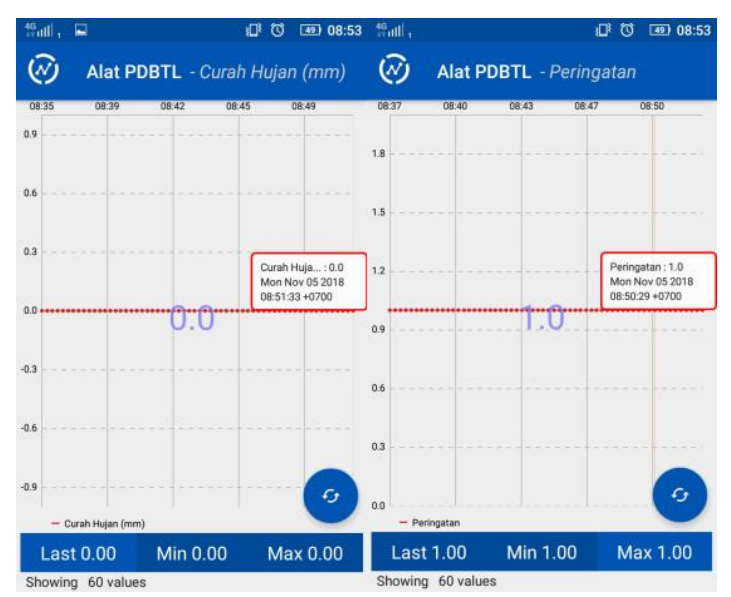

Gambar 10 tampilan pada smartphone

\section{Kesimpulan}

Diseminasi informasi dengan menggunakan teknologi IoT dapat berjalan dengan baik. Informasi dapat terkirim melalui jaringan komunikasi internet yang sangat tergantung pada ketersediaan jaringan internet dari provider di lokasi pemasangan sistem. Selama beroperasi sistem belum sepenuhnya menunjukan kehandalan yang baik, hal ini ditunjukan pada beberapa waktu sistem mengalami keadaan tidak mengirimkan data. Pengembangan selanjutnya membuat suatu pemberitahuan secara otomatis apabila tingkat kerawanan berada pada peringatan tinggi hingga ekstrim. Selain itu diseminasi informasi yang diperluas lagi dengan mengunakan protokol komunikasi yang lebih tepat.

\section{Ucapan Terima Kasih}

Ucapan terimakasih kepada Unit Penelitian dan Pengabdian Kepada Masyarakat (UP2KM) Sekolah Tinggi Meteorologi Klimatologi dan Geofisika yang telah membantu dalam pendanaan penelitian kajian Instrumentasi-MKG.

\section{Daftar Pustaka}

[1] Liao, Y. Hong, J. Wang, H. Fukuoka, K. Sassa, D. Karnawati, and F. Fathani," Prototyping An Experimental Early Warning System For Rainfall-Induced Landslides in Indonesia Using Satellite Remote Sensing and Geospatial Datasets," Landslides. Vol.7, Issue 3, pp 317324, September 2010.

[2] Darsono, B. Nurlaksito, B. Legowo, "Identifikasi Bidang Gelincir Pemicu Bencana Tanah Longsor Dengan Metode Resistivitas 2 Dimensi Di Desa Pablengan Kecamatan Matesih Kabupaten Karanganyar," Indonesian Journal of Applied Physics. Vol.2, No.1, pp.51, April 2012.

[3] UNEP, "Early warning systems: A state of the art analysis and future directions," Division of Early Warning and Assessment (DEWA), United Nations Environment Programme (UNEP), Nairobi, 2012.

[4] E. Bassar, "Diseminasi Informasi Publik Tentang Peringatan Dini Bencana," Jurnal Visi Komunikasi. Vol. 14, No. 1, pp.90 -103, Mei 2015.

[5] A.Dinagar P.Karthick, K.Karthi, P.Tamilvanan, and S.Premkumar, "Landslide Monitoring System with GSM Module," International Journal of Innovative Research in Computer and Communication Engineering. Vol. 3, Special Issue 2, March 2015.

[6] S.K Mittal, M. Singh, P. Kapur, B.K. Sharma and M. A. Shamshi, "Design and Development of Instrumentation Network for Landslide Monitoring and Issue an Early Warning," Journal of scientific \& Industrial Research. Vol. 67, pp.361-365, May 2008.

[7] M. W. Sari, P. W. Ciptadi, dan R. H. Hardyanto, "Study of Smart Campus Development Using Internet of Things Technology," International conference on Electrical Engineering, Computer Science and Informatics. IOP Conf. Ser. Mater. Sci. Eng. 190, 2017. 
[8] Winasis, A. W. W. Nugraha, I. Rosyadi, dan F. S. T. Nugroho," Desain Sistem Monitoring Sistem Photovoltaic Berbasis IoT," Jurnal Nasional Teknik elektro dan Teknik Informasi. Vol 5, No.4, 328-333, September 2016.

[9] A. Bhosale, P. Nimbore, S. Shitole, and 0. Govindwar, "Landslides Monitoring System
Using IoT," Imperial Journal of Interdisciplinary Research. Vol.3, Issue 4, 2017.

[10]A. Safril, A. Kristianto, D. Septiadi, dkk. "Kajian Awal Sistem Peringatan Dini Longsor Berbasis Penguatan Sistem Prediksi Curah Hujan dan Gempabumi Studi Area: Garut dan Banjarnegara," Monograf, UP2KM STMKG, Jakarta. (2017). 